\title{
Crevasses triggered on Pine Island Glacier, West Antarctica, by drilling through an exceptional melt layer
}

\author{
Julian B.T. SCOTT, Andrew M. SMITH, Robert G. BINGHAM, David G. VAUGHAN \\ British Antarctic Survey, Natural Environment Research Council, Madingley Road, Cambridge CB3 OET, UK \\ E-mail: jbts@bas.ac.uk
}

\begin{abstract}
The basic theory of crevasse formation suggests that crevasses initiate at or near the surface. However, due to variations in stress with depth, it has been suggested that it is possible for crevasses to initiate at depths of 10-30 m. From December 2006 to January 2007, hot-water drilling on Pine Island Glacier, West Antarctica, was found to trigger crevasses. Satellite imagery and field investigations in 2008, including ice cores, radar and GPS, revealed that these formed a new band of arcuate (curvilinear) crevasses around $70 \mathrm{~km}$ long and $100 \mathrm{~m}$ deep. This new band is located $10 \mathrm{~km}$ upstream from the previous limit of the arcuate crevasse zone. The crevasses were triggered on drilling through an exceptional ice layer at $>20 \mathrm{~m}$ depth. Ice layers within the firn will change both the strength and stress intensity. As the firn changes spatially and temporally (e.g. with the burial of an ice layer), it is possible for the position of crevasse initiation to change whilst the along-stream strain-rate profile remains constant. However, the main cause of an upstream migration of the arcuate crevasse zone on Pine Island Glacier is still likely to be an increase in strain rate.
\end{abstract}

\section{INTRODUCTION}

Crevasses are fractures in ice that form under tension. A tensile stress acts to pull the ice or firn apart and a lithostatic stress, or ice overburden, acts to push the ice back together. The lithostatic stress increases with depth, limiting the depth penetration of the crevasse (e.g. Van der Veen, 1998). It is generally considered that crevasses begin with starter cracks at or near the surface. However, Nath and Vaughan (2003) demonstrated that it is theoretically possible for a crevasse to initiate at depths of $10-30 \mathrm{~m}$. They took into account the variation in tensile stress with depth, due to firn compaction, whilst considering the strain rate to be constant with depth. They argued that if a crevasse triggered at depth can form without breaking the surface, it would call into question the use of buried crevasses in the calculation of ice-stream stagnation times (e.g. Retzlaff and Bentley, 1993).

The existence of an extensive arcuate (curvilinear) crevasse region across the width of Pine Island Glacier, West Antarctica, (Fig. 1) was first identified by Lucchitta and others (1995) from European Remote-sensing Satellite-1 (ERS-1) synthetic aperture radar (SAR) images. They noted that the upstream limit (or onset) of these features had moved slightly upstream over the 10 months between their two images taken in 1992. Rabus and Lang (2003) noted further inland migration of the arcuate crevassing between 1992 and 2000 , at a rate of approximately $100 \mathrm{~m} \mathrm{a}^{-1}$. It is reasonable to assume that given spatially and temporally constant firn properties, crevassing will start when the strain rate reaches a certain value. As the velocity profile of Pine Island Glacier steepens, with greater acceleration downstream than upstream (e.g. Scott and others, 2009), this strain rate will increase, allowing crevasses to form further upstream, as has been observed. However, if the firn properties were to vary spatially or temporally this may influence the stress and the strength of the firn to resist crevassing, hence affecting crevasse formation. It may be important to consider these variations, using for example an approach similar to that used by Nath and Vaughan (2003) when accounting for the variation in firn properties with depth.
Here we present some unique results from two field campaigns on Pine Island Glacier (2006-08). From the first, we present evidence of the formation of new arcuate crevasses; from the second, we present a variety of data acquired opportunistically on these crevasses, including from radar surveys. We examine a theoretical model to account for the formation of these new crevasses.

\section{METHODS}

A seismic reflection survey was conducted on Pine Island Glacier from December 2006 to January 2007 (A. Smith and J. Scott, http://neptune.gsfc.nasa.gov/wais/pastmeetings/ abstracts07/SmithA.pdf). For this survey, $300 \mathrm{~g}$ high-explosive charges were placed at the bottom of $24 \mathrm{~m}$ shot-holes. There were 67 holes across-stream and 17 along-stream at a regular spacing of $240 \mathrm{~m}$. These holes were drilled using a sledge-mounted hot-water drill, with the hose lowered by hand, along the two lines marked in Figure 2.

In the first field season (2006/07), three cores 19-22 m in depth were retrieved using a manual drill. One core was near the GPS station (marked in Fig. 2), and the others $10 \mathrm{~km}$ to the north and south. These cores were measured for density at regular intervals using electronic scales and vernier callipers, either in the field or in a cold room after shipment back to the UK. Preliminary dating of the cores was done by identifying characteristic annual conductivity peaks by scratching along the core with an electrical conductivity meter. During the following field season (2007/08), a further core was retrieved from around $40 \mathrm{~km}$ upstream. This was done in order to retrieve ice from a prominent radar reflector at the point where it came closest to the surface.

A pulseEKKO ground-penetrating radar (GPR) was used to profile along the ice-stream central flowline (determined using interferometric SAR (InSAR) velocities from Joughin and others, 2003). Along-stream profiles were around $100 \mathrm{~km}$ in length, starting at the location determined to be the onset of the arcuate crevasse zone and extending upstream. These profiles were made at frequencies of 25 and 


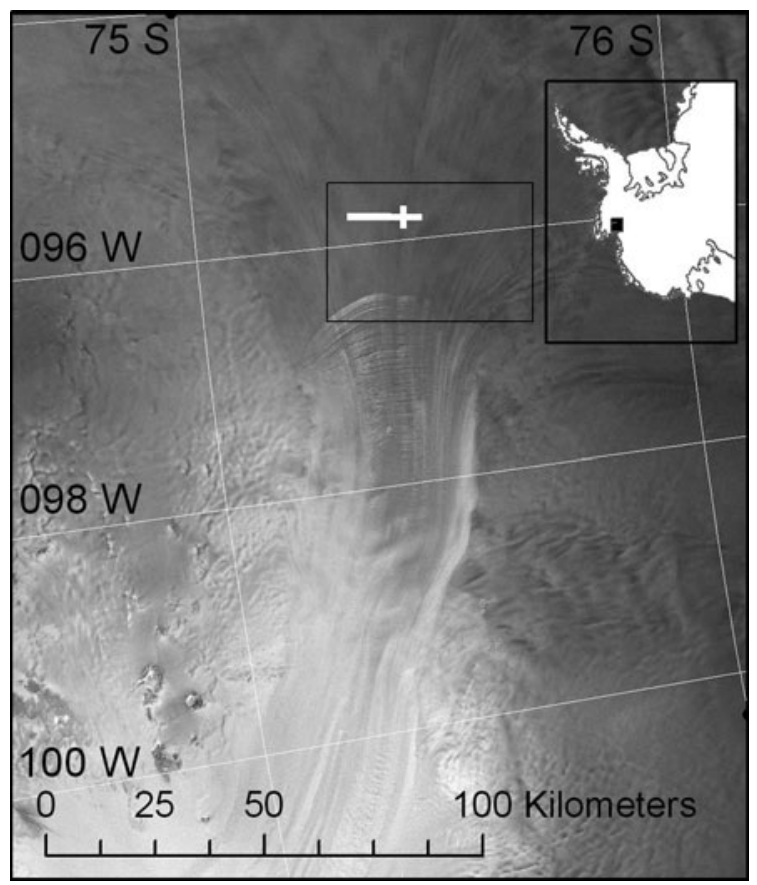

Fig. 1. Map of Pine Island Glacier. The 2006/07 seismic line is shown in white within a rectangular box delineating the area of Figure 2. Background is the RAMP (RADARSAT-1 Antarctic Mapping Project) 1997 Mosaic (K. Jezek and RAMP Product Team, http://nsidc.org/ data/nsidc-0103.html). Arcuate crevasses, seen as lighter arcs in the image, start around $15-20 \mathrm{~km}$ from the seismic line.

$500 \mathrm{MHz}$ in late January 2008. A $20 \mathrm{~km}$ profile was made across the ice stream, at $500 \mathrm{MHz}$ only, in mid-November 2007. The cross-stream profile ran parallel to the seismic line. The locations of the cross-stream profile and the downstream section of the along-stream profile are shown in Figure 2. Profiles were made towing the radar by skidoo, with a GPS unit recording position every second; these positions were processed against a static base station using the software Leica Geo Office. The $25 \mathrm{MHz}$ transmitter and receiver were pulled in line with the profile direction at a separation of $4.1 \mathrm{~m}$ and with the long axis of the antennas perpendicular to the profile. The $500 \mathrm{MHz}$ transducers were also pulled in line with the profile at a separation of $0.25 \mathrm{~m}$. The radar was optimized for tracking layers over long distances for mapping accumulation. Therefore some stacking of traces was done on data collection to reduce file sizes. The radar was towed at around $20 \mathrm{~km} \mathrm{~h}^{-1}$. This means that the radar was not set optimally for the crevasse mapping discussed in this paper.

To convert the radar two-way travel times to depth, the density measurements from the four ice cores were averaged, giving a density profile for the upper $20 \mathrm{~m}$. This was extrapolated through the firn column by fitting the empirical relationship of Schytt (1958):

$$
\rho=\rho_{\mathrm{i}}-\left(\rho_{\mathrm{i}}-\rho_{\mathrm{s}}\right) \mathrm{e}^{-\mathrm{C} z},
$$

where $\rho$ is the density at depth $z, \rho_{\mathrm{i}}$ is the density of ice $\left(917 \mathrm{~kg} \mathrm{~m}^{-3}\right), \rho_{\mathrm{s}}$ is the density of surface snow and $\mathrm{C}$ is a constant for the location. This relationship was fitted to the core densities from 5 to $20 \mathrm{~m}$ to avoid complex near-surface variations. The density was converted to electromagnetic velocity, $v_{\text {firn, }}$ using the following equations (Glen and Paren, 1975; Ulaby and others, 1986):

$$
\begin{gathered}
\varepsilon^{\prime}=\left[1+\left(5.08 \times 10^{-4} \rho\right)\right]^{3} \\
v_{\text {firn }}=\frac{C}{\sqrt{\varepsilon^{\prime}}},
\end{gathered}
$$

where $\varepsilon^{\prime}$ is the relative dielectric permittivity, $c$ is the speed of light in vacuum and $\rho$ is the density (in $\mathrm{kg} \mathrm{m}^{-3}$ ). Here we use the Looyenga-type Equation (2) rather than the widely used Kovacs formula (Kovacs and others, 1995). For firn

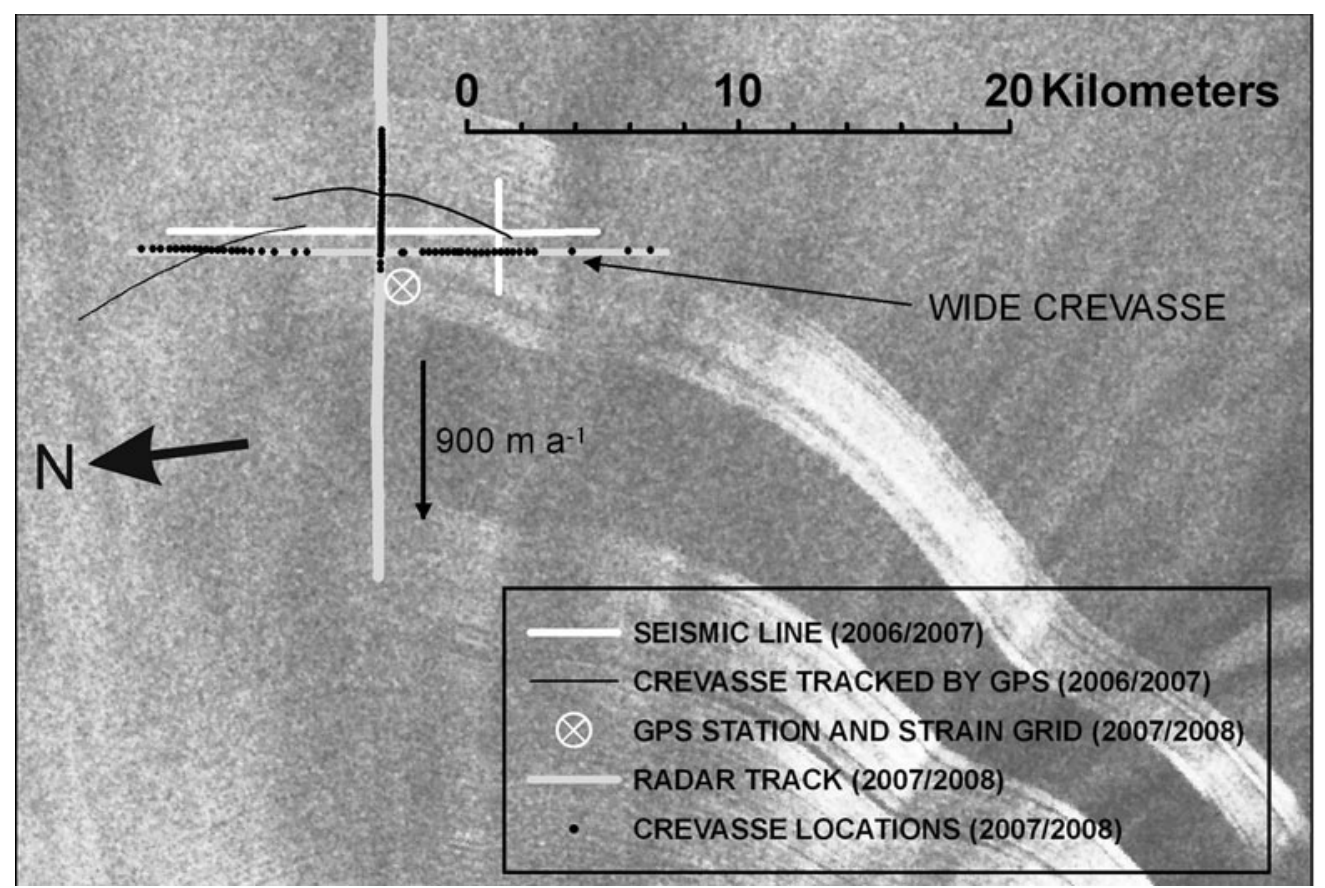

Fig. 2. Map of working area on Pine Island Glacier (location marked in Fig. 1). The seismic survey line and crevasse track locations from the 2006/07 season are marked. The GPR tracks and crevasse locations from the GPR survey from the 2007/08 season are marked. Background is an Envisat ASAR image from 8 May 2009. 
densities above $520 \mathrm{~kg} \mathrm{~m}^{-3}$ (around $3 \mathrm{~m}$ depth here), there is around $1 \%$ or less difference between the velocities derived from the two formulas. Equation (2) was found to work well for shallow snow pits on the Greenland ice cap with average firn densities of $300-560 \mathrm{~kg} \mathrm{~m}^{-3}$ (Scott and others, 2006). We converted radar-wave two-way travel time to depth by calculating the average velocity for every $0.1 \mathrm{~m}$ depth range and summing the travel times over these sections.

A GPS receiver placed on a metal pole recorded position at $10 \mathrm{~s}$ intervals from November 2007 to February 2009. The location of this receiver is shown in Figure 2 (PC111 in Scott and others, 2009). The positions of four further poles located $1 \mathrm{~km}$ upstream, downstream and in both directions crossstream were recorded by GPS on 15 November 2006 and 31 January 2007. From these the surface strain rate was calculated along-stream and cross-stream. This was done four times, using three different poles each time to give a triangular grid. This gave an estimate of the accuracy of the strain-rate measurements.

We used Envisat Advanced Synthetic Aperture Radar (ASAR) and ERS-2 SAR imagery from the European Space Agency to measure any changes in the position of the arcuate crevasses. These data were converted into GeoTIFF format. Viewing and measurement was done using the ArcMap software in south polar stereographic projection.

\section{FORMATION OF THE CREVASSES}

Hot-water drilling commenced on 13 December 2006, when 22 shot-holes were drilled and loaded with explosive. No visible cracks or crevasses had been noted in the area at this time. From 14 to 18 December these 22 explosive charges were detonated. A $10 \mathrm{~km}$ wide reconnaissance of the area on 20 December located a crack in the ice around $5 \mathrm{~km}$ away from the seismic line. This crack was traced along the surface back to one of the shot-points. No other cracks were found at this time.

On 22 December, 20 shot-holes were drilled. On drilling it was noted that 1-2 $\mathrm{m}$ before the bottom of the holes there was a particularly difficult layer to penetrate. On breaking through this layer, a sharp cracking sound was heard, sometimes accompanied by a small jolt felt through the legs. On each of these occasions a fresh crack appeared in the ice around $1-5 \mathrm{~mm}$ wide, usually between the drillers' legs. Drilling for the main seismic lines ended on 5 January 2007. Approximately half of the holes drilled had triggered these cracks. Detonating the explosives for the main seismic lines was completed on 15 January, when it was noted that two cracks formed on detonation where there had been no crack previously. The cases where cracks formed on detonation were the exceptions; this suggests that in most cases where a crack formed the drilling was an adequate trigger.

Two of the cracks triggered by the hot-water drilling were tracked along the surface using GPS (on 24 December 2006). Each of these was found to be $>10 \mathrm{~km}$ long and curved, with a radius of curvature similar to that of the preexisting arcuate crevasses downstream. One of the cracks continued further in either direction and we were unable to follow it to the end. The GPS tracks of these two cracks are shown in Figure 2. One of the cracks was measured at its widest point, several kilometres away from the shot-point. On 21 December it was $20 \mathrm{~mm}$ wide at this point and on 24 December it had expanded to $30 \mathrm{~mm}$. A heavy snowfall prevented further measurement of the width after this.

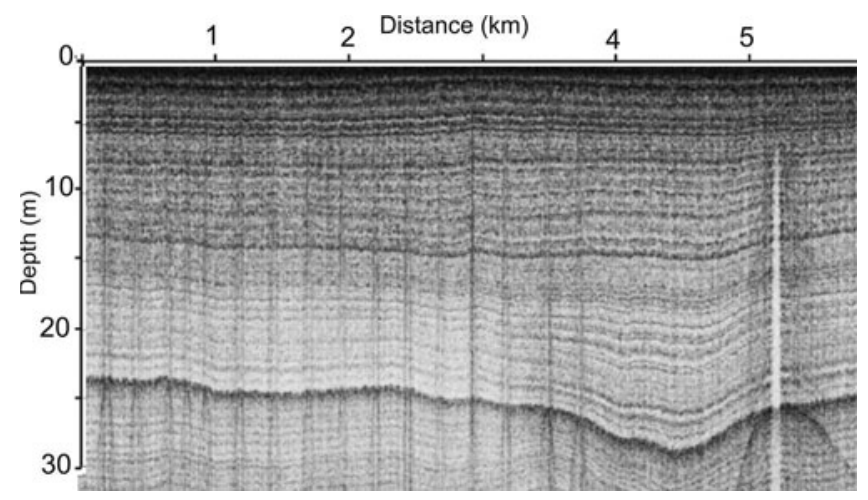

Fig. 3. Section from the $500 \mathrm{MHz}$ cross-stream radar profile, viewed looking upstream. Wide crevasse to right of section is marked in Figure 2.

\section{SATELLITE IMAGERY}

The Envisat ASAR imagery and ERS-2 SAR imagery show that the onset of the arcuate crevasse zone migrated upstream by around $5.5 \mathrm{~km}$ from the end of 2000 to the end of 2004. Its position then remained relatively stable up until the image of 16 December 2006. At this time the onset, or upstream limit, of the crevasses was approximately $10 \mathrm{~km}$ downstream from the seismic line. In the next available image, 3 weeks later on 7 January 2007, a new band of arcuate crevasses had appeared across the width of the ice stream. These crevasses cross our seismic line. They were therefore absent before we noticed the first cracks that we had triggered and were present immediately after completion of our drilling.

The downstream limit of this new band was level with the downstream limit of our seismic line. In Figure 2 we display a more recent Envisat ASAR image from 8 May 2009. This new band of upstream arcuate crevasses can still be seen as distinct and separate from the main arcuate crevasse zone, which has not migrated upstream since 2006. This new band of crevasses stretches across the width of the ice stream and is $>70 \mathrm{~km}$ long. The downstream end of this new section has moved downstream from the seismic survey location at the velocity of the ice stream. An interesting point to note is that the upstream end of the new band of crevasses appears to have migrated even further upstream since the creation of the band.

\section{GROUND-PENETRATING RADAR RESULTS}

The GPR survey took place 1 year after the seismic survey. During the GPR survey, no cracks were observed, although several small crevasses were observed around $10-20 \mathrm{~km}$ to the north and south. A section of the $500 \mathrm{MHz}$ cross-stream profile is shown in Figure 3. A number of regularly spaced vertical features can be seen to the left of the section. These come close to the surface (within 1-2 m, which is approximately the range of the annual accumulation), and the spacing is around the same as that of the shot-points (240 m); the cross-stream GPR profile ran parallel to the shot-line, not along it, so it is not reflections from the shot-points themselves that are being seen. On closer inspection, diffractions can be seen as they pass through prominent reflectors, particularly the strongest reflecting horizon, 


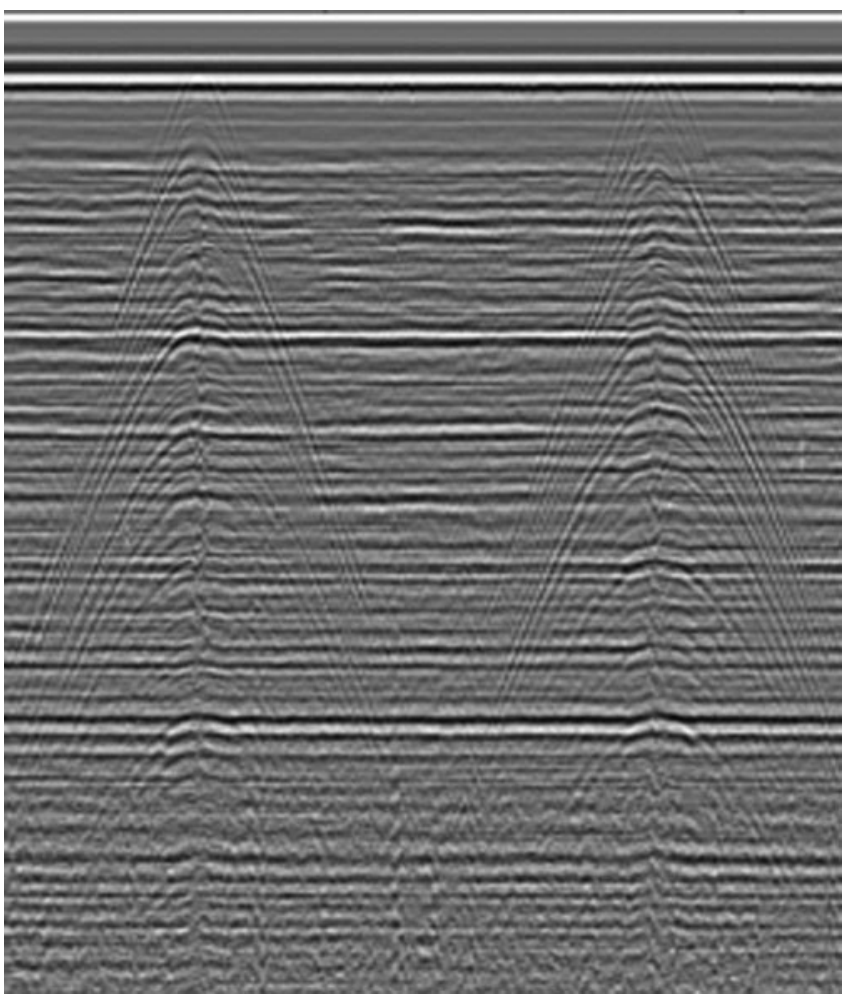

Fig. 4. Section from the $25 \mathrm{MHz}$ along-stream radar profile, showing two typical crevasses. Total width of the profile displayed is $400 \mathrm{~m}$. Total two-way travel time displayed is $1400 \mathrm{~ns}(125 \mathrm{~m})$.

around $25 \mathrm{~m}$ depth. These vertical features are interpreted as crevasses. A total of 43 of these crevasses were identified in the cross-stream profile and 45 in the along-stream profile (locations in Fig. 2). In the along-stream profile, that crossed the crevasses at right angles, the crevasse separation was around $100 \mathrm{~m}$. It is not possible to estimate the width of the crevasses at the low horizontal resolution of the survey. However, one crevasse which is wider than the others can be seen to the right of the section (Fig. 3). The top of this crevasse is at around $7 \mathrm{~m}$ depth, making it distinct from the other crevasses, and it is $>5 \mathrm{~m}$ wide.

There was a consistently clear band, or layer, of strong reflections identified in the $500 \mathrm{MHz}$ survey. This was at around $22-28 \mathrm{~m}$ depth in the vicinity of the seismic lines and would have been up to $1 \mathrm{~m}$ nearer to the surface during the drilling. The layer extends beyond the radar survey, which finishes $95 \mathrm{~km}$ upstream from the seismic line, and the reflecting band is at its thickest at the downstream end. The layer comes closest to the surface $40 \mathrm{~km}$ upstream from the seismic line at a depth estimated from the radar to be around $20.4 \mathrm{~m}$. It was decided to extract a core at this point. The core revealed a $20 \mathrm{~cm}$ thick very icy firn layer, with individual ice features up to $4 \mathrm{~cm}$ across. The top of this layer was at $20.36 \mathrm{~m}$. No other ice layer $>1 \mathrm{~mm}$ thick was found in the entire $22 \mathrm{~m}$ of core.

The $25 \mathrm{MHz}$ along-stream radar profile identified the same 45 crevasses as the $500 \mathrm{MHz}$ profile. Two typical crevasses are displayed in Figure 4. Diffractions can be clearly seen through several prominent reflectors including one calculated to be at $100 \mathrm{~m}$ depth. From this it is evident that the crevasses penetrate to at least $100 \mathrm{~m}$ depth. Deeper diffractions cannot be identified from any of the crevasses.

\section{THEORETICAL MODEL OF CREVASSE FORMATION AND PENETRATION}

The theoretical penetration depth for a surface crevasse can be calculated following the method outlined by Van der Veen (1998), which can be briefly summarized by

$$
K_{\mathrm{l}}^{\text {(tensile) }}\left(R_{X X}, d\right)+K_{\mathrm{l}}^{\text {(lithostatic) }}(d)>K_{\mathrm{l}}^{\text {(critical) }},
$$

where the tensile stress intensity factor, $K_{l}^{\text {(tensile) }}$, is positive and a function of the tensile resistive stress, $R_{x x}$ (approximately the surface stress), and the depth, $d$. The lithostatic stress intensity factor, $K_{l}^{\text {(lithostatic) }}$, is negative and a function of depth. The lithostatic stress acts to close the crevasse. The sum of these must be above some small critical stress intensity, $K_{l}{ }^{\text {(critical) }}$, for a crevasse to exist. This is a measure of the strength of the ice to resist being pulled apart. From our strain grid we calculated an along-stream extensional strain rate, $\varepsilon_{x x}=0.018 \mathrm{a}^{-1}$, an across-stream compressive strain rate, $\varepsilon_{y y}=-0.015 \mathrm{a}^{-1}$ and a shear strain rate, $\varepsilon_{x y}=$ $-0.006 \mathrm{a}^{-1}$. From this we calculated $R_{x x}=230 \mathrm{kPa}$ (Van der Veen, 1999, p. 38) using material parameters for the ice of $n=3$ and $A=1.3 \times 10^{-16} \mathrm{~s}^{-1} \mathrm{kPa}^{-3}$ (for our $20 \mathrm{~m}$ core temperature of $-21.9^{\circ} \mathrm{C}$ : Paterson, 1994). This method gives a maximum penetration depth of $55 \mathrm{~m}$ from Equation (4). The density at $55 \mathrm{~m}$ is around $850 \mathrm{~kg} \mathrm{~m}^{-3}$. The penetration depth is not altered significantly by varying $K_{\mathrm{l}}^{\text {(critical) }}$ between 100 and $400 \mathrm{kPam}^{1 / 2}$, as was also noted for water-filled crevasses (Van der Veen, 2007). A resistive stress $R_{x x} \approx 450 \mathrm{kPa}$ would be needed to give a depth of around $100 \mathrm{~m}$. However, the parameters $n$ and $A$ are not well defined and it is possible within the errors in these parameters to obtain a theoretical crevasse penetration depth of the order of $100 \mathrm{~m}$. It is also possible that the calculated value of the lithostatic stress is too high; the largest error in this is the extrapolation to depth from the base of our core at around $20 \mathrm{~m}$ (by the relationship of Schytt, 1958). It may also be necessary to account for the high stresses in other directions than along-stream. In summary, it appears that the depths of the crevasses that we have measured, of $100 \mathrm{~m}$, are high but not beyond the bounds of uncertainty in the theory.

The icy layer observed is exceptional and will have different physical properties than the surrounding firn. At the location of the new crevasses, the density of the firn, at $22 \mathrm{~m}$ depth, is $685 \pm 35 \mathrm{~kg} \mathrm{~m}^{-3}$. From the experimental results of Rist and others (1999, fig. 9) this density would result in a critical stress intensity factor, $K_{l}^{\text {(critical) }}=95 \pm 25 \mathrm{kPam}^{1 / 2}$. The exact density of the melt layer at the point of crevassing is unknown. Estimating a density of $800 \mathrm{~kg} \mathrm{~m}^{-3}$ would give $K_{\mathrm{l}}^{\text {(critical) }}=120 \pm 25 \mathrm{kPam}^{1 / 2}$. At this depth, because the densities are lower than that of glacier ice, the resistive stress would be lower than that used for the depth penetration calculation above. From the results of Mellor (1975), Nath and Vaughan (2003) calculate that for a density range of $600-915 \mathrm{~kg} \mathrm{~m}^{-3}$, and a resistive stress in ice of $250 \mathrm{kPa}$, the resistive stress can be approximately related to density by

$$
R_{X X}(\rho) \approx 12850 \mathrm{e}^{0.003243 \rho} .
$$

Although this is for a $20 \mathrm{kPa}$ higher resistive stress in ice than calculated for the area, the errors in the method make this a reasonable approximation. Equation (5) gives $R_{x x}=170 \mathrm{kPa}$ for the melt layer and $R_{x x}=120 \mathrm{kPa}$ for the surrounding firn. Following the methodology of Nath and Vaughan (2003, 
equation 5) and using a crack geometry factor, $\beta=1.12$ (Van der Veen, 2007), the melt layer would require a starter crack length of around $1.8 \mathrm{~m}$. The resistive stress in the surrounding firn is around the same magnitude as the lithostatic stress. Therefore, although weaker, the forces in the surrounding firn would balance, so starter cracks would not be expected to develop into crevasses at $22 \mathrm{~m}$ depth in this location. This model does not address the issue of stress distributions in inhomogeneous materials, so the uncertainties in the size of the starter crack needed are potentially large. The speed of crevasse growth suggests that the critical stress intensity was surpassed rather than a subcritical mechanism suggested by Weiss (2004).

\section{DISCUSSION AND CONCLUSIONS}

The evidence we have outlined in this paper suggests that we have triggered a new band of arcuate crevasses on Pine Island Glacier starting approximately $10 \mathrm{~km}$ upstream from the previous onset position. Envisat ASAR images show that this band formed sometime during a 3 week period when we drilled over 70 shot-holes to around $24 \mathrm{~m}$ depth with a hotwater drill. The appearance and location of this band coincides exactly with our drilling activities. We were aware of cracks forming from the drilling at the time, and early GPS investigations suggested that these were arcuate in shape. It was noted during the drilling that these crevasses formed on breaking through a hard layer, at around $22 \mathrm{~m}$ depth. Radar investigations the following season revealed a strong reflector at this depth. An ice core, $40 \mathrm{~km}$ upstream from the seismic line, revealed that this reflector coincided with an exceptional melt layer, consisting of around $20 \mathrm{~cm}$ of very icy firn. In fact this was the only percolation feature noted in the entire $22 \mathrm{~m}$ of core. It is likely that at the location of the seismic line, $40 \mathrm{~km}$ nearer to the coast and at lower elevation, this melt feature is even thicker. Our hypothesis is that this layer held a far higher stress than the surrounding firn. It was the initiation of a crack in this layer through our drilling which triggered the crevasse, releasing the stress locally. Theoretically, a starter crack of around $2 \mathrm{~m}$ is needed. This is possible because as the drill reached the hard impermeable ice layer, the water would have spread laterally, melting a much greater area than the width of the drill. However, the uncertainty in the size of the starter crack needed is high. What this study dramatically underlines is the limitation of simple models that assume constant material properties and applied tensile stresses. It is notable that without the trigger of drilling, the crevasses were forming naturally $10 \mathrm{~km}$ downstream. At the local speed of around $0.9 \mathrm{~km} \mathrm{a}^{-1}$ (Scott and others, 2009) this layer may not have split naturally for another 11 years.

It is possible that the burial of the icy layer through natural accumulation will change the overall firn properties enough to alter the critical level of the strain rate which is needed to form crevasses. The presence of even an individual ice layer of this size should be accounted for when modelling crevasse creation and penetration because these layers may be far more important than the surrounding weaker firn. This may have implications for the study of crevasse formation and penetration in more marginal areas of Antarctica such as on ice shelves and in the percolation zone of Greenland.

The upstream migration of the arcuate crevasse zone on Pine Island Glacier was very fast between 2000 and 2004 and has been stable since then. It is therefore unlikely that this migration was due to changing firn properties and it is genuinely a result of the strain rate increasing upstream. The results presented by Scott and others (2009) have shown that the strain rate over this part of the glacier is increasing. However, because of the changing firn properties it will not be possible to directly associate the onset of the arcuate crevasse zone with a particular, critical level of strain. Also because of the widespread disturbance caused by our field activities it will now be difficult to infer changes in ice dynamics from migration of the arcuate crevasse band, as previously done by Rabus and Lang (2003).

We note that all of the crevasses, which we have created at depth, appear to have broken the surface. Therefore, on one hand this study reinforces the theory of Nath and Vaughan (2003) by finding direct evidence of crevasse creation at depth. However, evidence has still to be found that these crevasses, initiated at depth, do not always reach the surface. Until this evidence is found, the calculation of ice-stream stagnation times, from the depth of crevasse burial alone, can be considered reasonable.

Another finding of this study is that using the Looyengatype equation (Equation (2)) gave a good travel-time to depth conversion for the upper $20 \mathrm{~m}$ of firn. This is making the reasonable assumption that the top of the ice layer is the prominent radar reflector observed. As Equation (2) gives very similar results to the Kovacs formula for higher-density ice, below $20 \mathrm{~m}$, it is appropriate to use it in this area in place of the more commonly used Kovacs formula.

\section{ACKNOWLEDGEMENTS}

This work was supported by the UK Natural Environment Research Council, Geophysical Equipment Facility (Loan 847). We thank F. Buckley, C. Griffiths, R. Smith and R. Stilwell for assistance with the fieldwork and A. Fleming for assistance with satellite imagery. We also thank D. Benn for his review which helped improve the paper.

\section{REFERENCES}

Glen, J.W. and J.G. Paren. 1975. The electrical properties of snow and ice. J. Glaciol., 15(73), 15-38.

Joughin, I., E. Rignot, C.E. Rosanova, B.K. Lucchitta and J. Bohlander. 2003. Timing of recent accelerations of Pine Island Glacier, Antarctica. Geophys. Res. Lett., 30(13), 1706. (10.1029/ 2003GL017609.)

Kovacs, A., A.J. Gow and R.M. Morey. 1995. The in-situ dielectric constant of polar firn revisited. Cold Reg. Sci. Technol., 23(3), 245-256.

Lucchitta, B.K., C.E. Rosanova and K.F. Mullins. 1995. Velocities of Pine Island Glacier, West Antarctica, from ERS-1 SAR images. Ann. Glaciol., 21, 277-283.

Mellor, M. 1975. A review of basic snow mechanics. IAHS Publ. 114 (Symposium at Grindelwald 1974 - Snow Mechanics), 251-291.

Nath, P.C. and D.G. Vaughan. 2003. Subsurface crevasse formation in glaciers and ice sheets. J. Geophys. Res., 108(B1), 2020. (10.1029/2001JB000453.)

Paterson, W.S.B. 1994. The physics of glaciers. Third edition. Oxford, etc., Elsevier.

Rabus, B.T. and O. Lang. 2003. Interannual surface velocity variations of Pine Island Glacier, West Antarctica. Ann. Glaciol., 36, 205-214. 
Retzlaff, R. and C.R. Bentley. 1993. Timing of stagnation of Ice Stream C, West Antarctica, from short-pulse radar studies of buried surface crevasses. J. Glaciol., 39(133), 553-561.

Rist, M.A. and 6 others. 1999. Experimental and theoretical fracture mechanics applied to Antarctic ice fracture and surface crevassing. J. Geophys. Res., 104(B2), 2973-2987.

Schytt, V. 1958. The inner structure of the ice shelf at Maudheim as shown by core drilling. Norwegian-British-Swedish Antarctic Expedition, 1949-52, Sci. Results, 4(2C). Oslo, Norsk Polarinstitutt, 113-151.

Scott, J., D. Mair, P. Nienow, V. Parry and E. Morris. 2006. A groundbased radar backscatter investigation in the percolation zone of the Greenland Ice Sheet. Remote Sens. Environ., 104(4), 361-373.

Scott, J.B.T., G.H. Gudmundsson, A.M. Smith, R.G. Bingham, H.D. Pritchard and D.G. Vaughan. 2009. Increased rate of acceleration on Pine Island Glacier strongly coupled to thinning induced changes in driving stress. Cryosphere, 3(1), 125-131.

Ulaby, F.T., R.K. Moore and A.K. Fung. 1986. Microwave remote sensing, active and passive. Vol. 3: From theory to applications. Reading, MA, Addison-Wesley.

Van der Veen, C.J. 1998. Fracture mechanics approach to penetration of surface crevasses on glaciers. Cold Reg. Sci. Technol., 27(1), 31-47.

Van der Veen, C.J. 1999. Fundamentals of glacier dynamics. Rotterdam, A.A. Balkema.

Van der Veen, C.J. 2007. Fracture propagation as means of rapidly transferring surface meltwater to the base of glaciers. Geophys. Res. Lett., 34(1), L01501. (10.1029/2006GL028385.)

Weiss, J. 2004. Subcritical crack propagation as a mechanism of crevasse formation and iceberg calving. J. Glaciol., 50(168), $109-115$. 